\title{
Genetic Variability of Phyllosticta ampelicida, the Agent of Black Rot Disease of Grapevine
}

\author{
Pietro A. Rinaldi, Donatella Paffetti,† Cecilia Comparini, Giovanni A. L. Broggini, Cesare Gessler, and Laura Mugnai
}

First, third, and sixth authors: Dipartimento di Scienze delle Produzioni Agroalimentari e dell'Ambiente-Sezione Patologia Vegetale ed Entomologia, P. le delle Cascine 28, 50144 Florence, Italy; second author: Dipartimento di Scienze delle Produzioni Agroalimentari e dell'Ambiente-Sezione Genetica Agraria, via Maragliano, 75-77, 50144 Florence, Italy; and fourth and fifth authors: Plant Pathology Institute of Integrative Biology, Swiss Federal Institute of Technology (IBZ) ETH Zurich Universitätstrasse, 2 8092, LFW-Zurich.

Current address of G. A. L. Broggini: Molecular Plant Breeding, Institute of Agricultural Sciences, ETH Zurich, CH-8092 Zurich. Accepted for publication 31 May 2017.

\begin{abstract}
Phyllosticta ampelicida causes black rot disease of Vitis spp. Genetic homogeneity of pathogen populations was investigated by analyzing the number of haplotypes present in infected samples from Europe and America. The fungus was identified from an analysis of the internal transcribed spacer (ITS)1-ITS2 region, and partial sequences of $\beta$-tubulin and calmodulin genes. The analysis of nuclear microsatellites applied to strains from Vitis spp. confirmed the existence of a high degree of genetic variability in the fungal populations, revealed four subpopulations, and showed that strains from

America are distinct from the European ones. Furthermore, the results obtained by landscape genetics showed that there were different introductions of the pathogen in the main vine areas of Europe, confirming what was observed in the first reports of the disease. The genetic variability of the fungus revealed by this study confirms the ability to generate new haplotypes by sexual reproduction. The difference found between the European populations and the American one confirms that the pathogen originated from America.
\end{abstract}

Phyllosticta ampelicida (Engelm.) Aa (syn. Guignardia bidwellii, following the recommendations of the International Commission on the Taxonomy of Fungi, Rossman et al. 2015) is the causal agent of black rot of grapevine, a devastating disease known throughout most of the grape-growing regions of the world. Disease symptoms can develop on all green tissues, forming cankers on the tendrils, leaf petioles, shoots, and rachis of the grapevine and round necrotic spots on the leaves (Molitor and Berkelmann-Loehnertz 2011; Molitor and Beyer 2014; Wilcox and Hoffman 2015). Infected berries can mummify within 1 to 2 weeks or more after infection and their surfaces soon become covered by pycnidia and, later, pseudothecia of the fungus. Damage on the clusters can be limited to single berries or can lead to complete mummification of the whole bunch. The mummified berries typically remain firmly attached to the cluster. Grapevines are most susceptible from 1 to 5 weeks after flowering, depending on the weather conditions (Hoffman and Wilcox 2002; Molitor and Berkelmann-Loehnertz 2011; Molitor and Beyer 2014).

The first reports of the disease were from Kentucky in the United States in 1805, when Michaux, during his travels, noticed symptoms of the disease on a farm near Lexington. In Europe, the pathogen was reported for the first time in France in 1885, in the upper Valley of Hérault, where vines from America had been introduced just 6 years before (Galet 1977). After this first introduction, the disease spread throughout Europe. The first report of the disease in Italy dates back to 1891 (Martelli 1891), when symptoms were reported only on the leaves. In the vine areas of the northeastern regions in Italy, it was assumed that the pathogen came from the neighboring Eastern European countries, probably from the former ex-Yugoslavia area, where the pathogen had been known since 1935 (Rui 1935). In 2002, black rot was recorded in Germany (Harms et al. 2005; Holz 2003), and the increasing spread worried the growers of Hungary (Mikulás et al. 1999) and, more recently, Romania (Tomoioaga and

${ }^{\dagger}$ Corresponding author: D. Paffetti; E-mail: donatella.paffetti@unifi.it

(C) 2017 The American Phytopathological Society
Comsa 2010), Portugal, and Italy (Rinaldi et al. 2013). The concern raised by the increasing incidence of the disease recently led European researchers to set up disease support systems to better control it (Molitor et al. 2016; Onesti et al. 2016).

The pathogen is responsible for black rot disease of species in several genera of the Vitaceae family such as Vitis, Ampelopsis, Cissus, and Parthenocissus (Wikee et al. 2011). The fungus was hypothesized to be indigenous to America, where the native vine species underwent a selective process for resistance (Reddick 1911). Luttrell (1946, 1948) demonstrated the existence of different forms of "G. bidwellii" based on morphological differences and differences in pathogenicity on 'Muscadine' grape (Vitis rotundifolia subgenus Muscadinia), $V$ vinifera, Parthenocissus spp., and American native grape. The form muscadinii, which mainly infects $V$. rotundifolia, causes primarily a disease of the vegetative parts, appearing as superficial scabs or lesions on the berries, and it can infect $V$. vinifera as well. The other two forms detected were $P$. ampelicida f. euvitis, pathogenic to $V$. vinifera and American species, and P. ampelicida f. parthenocissi, a pathogen of Parthenocissus spp. A study carried out by Zhang et al. (2013) demonstrated different species in the $P$. ampelicida complex, proposing $P$. parthenocissi as a distinct species based on phylogenetic and morphological data.

Several reasons could be hypothesized for the recent outbreaks of the disease. It is possible that strains resistant to the commonly used fungicides are naturally selected; transport of infected material from one vine-growing region to another could favor the introduction of strains more suited to the new environment; and multiplication of the fungus by both sexual and asexual means makes it particularly able to adapt to various environmental conditions. Another aspect possibly related to the recent increase in the spread of the disease is the recent changes in the management of powdery and downy mildew chemical control. Some of the chemicals used are also effective against black rot but, with the increased sensitivity toward the environment and the increasingly restrictive legislation of the European Union toward the use of pesticides, the application strategies have changed. Some broad-spectrum pesticides such as dithiocarbamates, which are very effective against $P$. ampelicida, are less used today, and application is 
carried out more and more specifically on powdery and downy mildew risk stages. These intervention strategies may have little or no effect on black rot. Therefore, conditions suitable for spread of the fungus in the most sensitive phenological stages of the vine can have drastic effects. Lack of knowledge of the typical symptoms and wrong diagnosis will increase the effect, as suggested by Gessler et al. (2006, 2008), and was ascertained in the recent outbreak in Italy (Rinaldi and Mugnai 2012).

Therefore, we investigated the genetic homogeneity of pathogen populations by analyzing the number of haplotypes present in infected samples from Europe and America. Analysis of the internal transcribed spacer (ITS)1-ITS2 region, $\beta$-tubulin, and calmodulin sequences was used to identify the pathogen (Wicht et al. 2012). Finally, microsatellites (nuclear simple-sequence repeat $[n \mathrm{SSR}]$ ) were used to assess the genetic variability of the fungus and to understand the migration flows of the pathogen and determine the genetic distance between the populations from different vine areas. Spatial analysis was also applied to assess genetic diversity of a $P$. ampelicida population in a single vineyard.

\section{MATERIALS AND METHODS}

Sampling, fungal isolation, and DNA extraction. Isolations were made from leaf necrotic spots, cane cankers, mummified

TABLE 1. Phyllosticta ampelicida strains used in pathogen identification analysis

\begin{tabular}{|c|c|c|c|c|c|}
\hline \multirow[b]{2}{*}{ ID } & \multirow[b]{2}{*}{ Provenance } & \multirow[b]{2}{*}{ Host (cultivar) } & \multicolumn{3}{|c|}{ GenBank accession number } \\
\hline & & & ITS $^{\mathrm{a}}$ & $\beta$-Tubulin & Calmodulin \\
\hline G1.2 & Mercatale (Tuscany, Italy) & Vitis vinifera L. (Sangiovese) & KF015253 & KF831472 & \\
\hline G1.6 & Mercatale (Tuscany, Italy) & V. vinifera $\mathrm{L}$. (Sangiovese) & KF015254 & KF831473 & KF831428 \\
\hline G1.7 & Mercatale (Tuscany, Italy) & V. vinifera L. (Sangiovese) & KF015255 & KF831474 & KF831429 \\
\hline G1.8 & Grassina (Tuscany, Italy) & V. vinifera L. (Sangiovese) & KF015256 & KF831475 & KF831430 \\
\hline G1.10 & Grassina (Tuscany, Italy) & V. vinifera $\mathrm{L}$. (Sangiovese) & KF015257 & KF831476 & KF831431 \\
\hline G1.12 & San Casciano (Tuscany, Italy) & $V$. vinifera $\mathrm{L}$. (Sangiovese) & KF015258 & KF831477 & KF831432 \\
\hline G1.13 & San Gimignano (Tuscany, Italy) & $V$. vinifera $\mathrm{L}$. (Sangiovese) & KF015259 & KF831478 & KF831433 \\
\hline G1.14 & San Gimignano (Tuscany, Italy) & V. vinifera $\mathrm{L}$. (Vernaccia) & KF015260 & KF831479 & KF831434 \\
\hline G1.15 & Quarrata (Tuscany, Italy) & V. vinifera $\mathrm{L}$. (Merlot) & KF015261 & KF831480 & KF831435 \\
\hline G1.16 & Quarrata (Tuscany, Italy) & V. vinifera $\mathrm{L}$. (Colorino) & KF015262 & KF831481 & KF831436 \\
\hline G1.17 & Florence (Tuscany, Italy) & V. vinifera L. (Sangiovese) & KF015263 & KF831482 & KF831437 \\
\hline G1.21 & Florence (Tuscany, Italy) & V. vinifera L. (Colorino) & KF015264 & KF831483 & KF831438 \\
\hline G1.29 & Rauscedo (Friuli-Venezia Giulia, Italy) & V. vinifera L. (Merlot) & KF015265 & KF831484 & KF831439 \\
\hline G1.30 & Rauscedo (Friuli-Venezia Giulia, Italy) & $V$. vinifera $\mathrm{L}$. (Merlot) & KF015266 & KF831485 & KF831440 \\
\hline G1.31 & Rauscedo (Friuli-Venezia Giulia, Italy) & $V$. vinifera L. (Merlot) & KF015267 & KF831486 & $\ldots$ \\
\hline G1.34 & Vezzano (Liguria, Italy) & V. vinifera $\mathrm{L}$ & KF015268 & KF831487 & KF831441 \\
\hline G1.35 & Vezzano (Liguria, Italy) & $V$. vinifera $\mathrm{L}$. & KF851288 & KF831488 & KF831442 \\
\hline SS01 & Oliena (Sardinia, Italy) & $V$. vinifera $\mathrm{L}$. & KF851289 & KF831489 & KF831443 \\
\hline SS02 & Sorso (Sardinia, Italy) & $V$. vinifera $\mathrm{L}$. & KF851290 & KF831490 & KF831444 \\
\hline Piem7/12 & Unknown (Piedmont, Italy) & $V$. vinifera $\mathrm{L}$ & KF851291 & KF831491 & KF831445 \\
\hline TVac1 & Treviso (Veneto, Italy) & $V$. vinifera L. (Merlot) & KF851292 & KF831492 & KF831446 \\
\hline TVac2 & Treviso (Veneto, Italy) & V. vinifera L. (Merlot) & KF851293 & KF831493 & KF831447 \\
\hline Lomb5 & Traona (Lombardia, Italy) & $V$. vinifera $\mathrm{L}$. & KF851294 & KF831494 & KF831448 \\
\hline Lomb7 & Traona (Lombardia, Italy) & $V$ vinifera $\mathrm{L}$. & KF851295 & KF831495 & KF831449 \\
\hline Lomb8 & Traona (Lombardia, Italy) & V. vinifera $\mathrm{L}$. & KF851296 & KF831496 & KF831450 \\
\hline POR2 & Lisboa (Lisboa, Portugal) & $V$. vinifera $\mathrm{L}$. & KF851297 & KF831497 & KF831451 \\
\hline POR11 & Lisboa (Lisboa, Portugal) & $V$. vinifera $\mathrm{L}$. & KF851298 & KF831498 & KF831452 \\
\hline POR12 & Lisboa (Lisboa, Portugal) & $V$ vinifera $\mathrm{L}$. & KF851299 & KF831499 & KF831453 \\
\hline POR19 & Lisboa (Lisboa, Portugal) & V. vinifera $\mathrm{L}$ & KF851300 & KF831500 & KF831454 \\
\hline HUNGI10.2 & Dula (Eger, Hungary) & V. vinifera L. (Kèkfrancos) & KF851301 & KF831501 & KF831455 \\
\hline HUNGI15.3 & Dula (Eger, Hungary) & V. vinifera L. (Kèkfrancos) & KF851302 & KF831502 & KF831456 \\
\hline HUNGI17.3 & Dula (Eger, Hungary) & V. vinifera $\mathrm{L}$. (Kèkfrancos) & KF851303 & KF831503 & KF831457 \\
\hline GM05 & Kindel (Mosel, Germany) & $V$ vinifera $\mathrm{L}$. (Muller-Thurgau) & KF851304 & KF831504 & KF831458 \\
\hline 121Li6 & Wolf (Mosel, Germany) & $V$ vinifera $\mathrm{L}$. & KF851309 & KF831509 & KF831463 \\
\hline FRA 6.2 & Rosieres (Midi-Pirenei, France) & V. vinifera L. (Gamay) & KF851305 & KF831505 & KF831459 \\
\hline FRA10.1 & Rosieres (Midi-Pirenei, France) & V. vinifera L. (Gamay) & KF851306 & KF831506 & KF831460 \\
\hline LUX3EC & Ehnen (Luxemburg) & $V$. vinifera $\mathrm{L}$. & KF851308 & KF831508 & KF831462 \\
\hline LUX3ES & Ehnen (Luxemburg) & $V$. vinifera $\mathrm{L}$ & KF851307 & KF831507 & KF831461 \\
\hline VirginiaG1A1 & Upperville (Virginia) & V. vinifera L. (Cabernet Sauvignon) & KF851310 & KF831510 & KF831464 \\
\hline VirginiaG8A1 & Upperville (Virginia) & V. vinifera L. (Cabernet Sauvignon) & KF851311 & KF831511 & KF831465 \\
\hline VirginiaG8A2 & Upperville (Virginia) & V. vinifera $\mathrm{L}$. (Cabernet Sauvignon) & KF851312 & KF831512 & KF831466 \\
\hline Pensyl 1 & Northeast (Pennsylvania) & V. labrusca L. (Concord) & KF851313 & KF831513 & KF831467 \\
\hline Pensyl 2 & Northeast (Pennsylvania) & V. labrusca L. (Concord) & KF851314 & KF831514 & KF831468 \\
\hline Pensyl 6 & Northeast (Pennsylvania) & V. labrusca L. (Concord) & KF851315 & KF831515 & KF831469 \\
\hline Pensyl 8 & Northeast (Pennsylvania) & V. labrusca L. (Concord) & KF851316 & KF831516 & KF831470 \\
\hline Pensyl 13 & Northeast (Pennsylvania) & V. labrusca L. (Concord) & KF851317 & KF831517 & KF831471 \\
\hline Sb9.5 & Salleboeuf (Aquitaine, France) & V. vinifera $\mathrm{L}$. (Merlot) & $\ldots$ & $\ldots$ & GU991587 \\
\hline $\mathrm{Sb} 22.6$ & Salleboeuf (Aquitaine, France) & V. vinifera L. (Merlot) & $\ldots$ & GU991580 & $\ldots$ \\
\hline $\mathrm{Sb} 25.7$ & Salleboeuf (Aquitaine, France) & $V$. vinifera L. (Merlot) & $\ldots$ & GU991581 & GU991586 \\
\hline $\mathrm{Sb} 28.3$ & Salleboeuf (Aquitaine, France) & $V$ vinifera $\mathrm{L}$. (Merlot) & $\ldots$ & HМ065512 & $\ldots$ \\
\hline Ti18.5.1 & Cugnasco (Ticino, Switzerland) & V. vinifera $\mathrm{L}$. (Chamboucin) & $\ldots$ & GU991579 & $\ldots$ \\
\hline Ti34.1.8 & Cugnasco (Ticino, Switzerland) & V. vinifera L. (Isabella) & $\ldots$ & GU991582 & $\ldots$ \\
\hline ATCC200578 & Unknown (New York) & V. riparia Michx. & KC193586 & $\ldots$ & $\ldots$ \\
\hline CBS111645 & Unknown (United States) & $\begin{array}{l}\text { Parthenocissus quinquefolia (L.) Planch., } \\
1887\end{array}$ & FJ824766 & FJ824777 & $\cdots$ \\
\hline MUCC0019 & Unknown (Aichi, Japan) & P. tricuspidata (Siebold \& Zucc.) Planch. & AB454268 & $\ldots$ & \\
\hline MUCC0120 & Unknown (Aichi, Japan) & P. tricuspidata (Siebold \& Zucc.) Planch. & AB454313 & $\ldots$ & $\ldots$ \\
\hline MUCC0037 & Unknown (Tokyo, Japan) & P. tricuspidata (Siebold \& Zucc.) Planch. & $\mathrm{AB} 454276$ & $\ldots$ & $\ldots$ \\
\hline
\end{tabular}

a Internal transcribed spacer. 


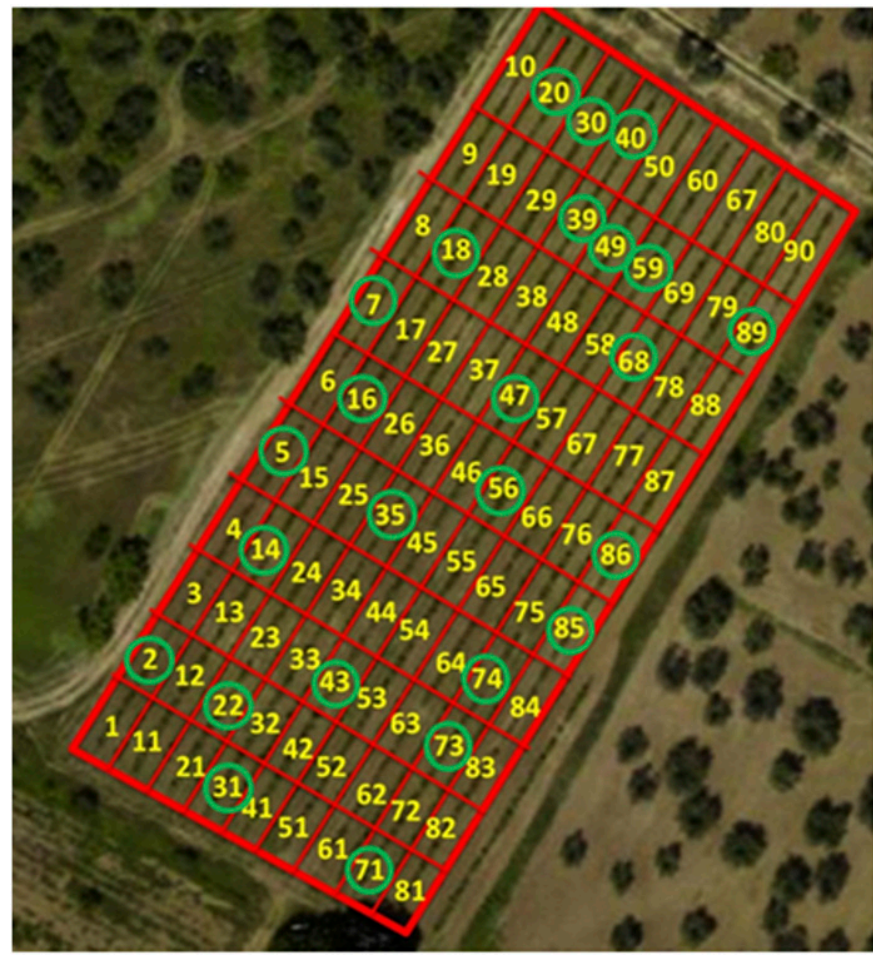

Fig. 1. Aerial view of the vineyard in Florence divided into 90 plots. From each plot, 1 infected cluster was collected and 25 of them (those whose number is enclosed in a circle) were analyzed with nuclear microsatellites. Map obtained from Google Earth. berries, and shriveled berries. The samples were collected in 2011 and 2012 in all of the central and northern Italian grapevine areas in which the disease was reported, in the main European countries where the disease is usually present, and in two U.S. states (Virginia and Pennsylvania) (Table 1). Only the samples from Pennsylvania are from V. labrusca; all of the others are from $V$. vinifera of international and local varieties. Samples were disinfected by immersion in $10 \%$ hydrogen peroxide for few seconds, followed by two washes with distilled water. The tissues were sectioned and placed on malt agar (MA) and left for 15 to 20 days at room temperature. Monohyphal isolates were obtained from actively growing colonies in the following way. A small sample of the pathogen mycelium was scraped from the surface of a colony grown on MA and placed in a sterilized 2-ml Eppendorf tube, and $1.5 \mathrm{ml}$ of sterile distilled water added. The tube was vortexed for $2 \mathrm{~min}$ and $30 \mu \mathrm{l}$ of the suspension was spread over a plate of water agar. A single-hyphal portion was selected and marked. When the colony was big enough to be visible, it was transferred to another MA dish. DNA was extracted from the mycelium with DNeasy Plant Mini Kit (Qiagen) according to the manufacturer's instructions.

A second sampling was carried out in a 35 -year-old vineyard $\left(5,000 \mathrm{~m}^{2}\right)$ growing on the hill of Montici, close to Pian De' Giullari, in the surroundings of Florence, Italy and planted with 'Sangiovese' and 'Trebbiano' grape. Heavy damage by $P$. ampelicida had been recorded in 2011, with $100 \%$ of the clusters in both cultivars completely dried up. The vineyard was divided into 90 rectangular plots (11 by $3 \mathrm{~m}$ each). Each plot included three rows (Fig. 1). In each plot, a mummified cluster, chosen at random, was collected from the middle row and stored at $4^{\circ} \mathrm{C}$. In all, 25 plots were selected at random although taking care to cover the entire surface of the vineyard, and

TABLE 2. Phyllosticta ampelicida strains used in nuclear microsatellites analysis

\begin{tabular}{|c|c|c|c|}
\hline ID & Provenance & Host (cultivar) & Number of samples \\
\hline A & Florence (Tuscany, Italy) & Vitis vinifera L. (Sangiovese) & 148 \\
\hline G & Florence (Tuscany, Italy) & V. vinifera $\mathrm{L}$. (Trebbiano) & 4 \\
\hline B & San Gimignano (Tuscany, Italy) & V. vinifera L. (Sangiovese) & 9 \\
\hline $\mathrm{D}$ & Grassina (Tuscany, Italy) & V. vinifera $\mathrm{L}$. & 11 \\
\hline E & San Casciano (Tuscany, Italy) & V. vinifera L. (Sangiovese) & 6 \\
\hline $\mathrm{F}$ & Strada in Chianti (Tuscany, Italy) & V. vinifera L. (Trebbiano) & 7 \\
\hline $\mathrm{H}$ & Mercatale (Tuscany, Italy) & V. vinifera L. (Sangiovese) & 5 \\
\hline $\mathrm{K}$ & Farra d'Isonzo (Friuli-Venezia Giulia, Italy) & V. vinifera L. (Pinot Grigio) & 4 \\
\hline $\mathrm{L}$ & Riomaggiore (Liguria, Italy) & $V$. vinifera $\mathrm{L}$. & 11 \\
\hline M & Vezzano (Liguria, Italy) & V. vinifera $\mathrm{L}$. & 25 \\
\hline $\mathrm{N}$ & Sarzana (Liguria, Italy) & V. vinifera $\mathrm{L}$. & 15 \\
\hline $\mathrm{O}$ & Calizzano (Liguria, Italy) & V. vinifera $\mathrm{L}$. & 3 \\
\hline $\mathrm{P}$ & Teglio (Lombardia, Italy) & V. vinifera $\mathrm{L}$. & 4 \\
\hline Q & Traona (Lombardia, Italy) & V. vinifera $\mathrm{L}$. & 4 \\
\hline W & Treviso (Veneto, Italy) & V. vinifera L. (Merlot) & 3 \\
\hline $\mathrm{X}$ & Oliena (Sardinia, Italy) & $V$. vinifera $\mathrm{L}$. & 1 \\
\hline Y & Sorso (Sardinia, Italy) & $V$ vinifera $\mathrm{L}$. & 1 \\
\hline $\mathrm{Z}$ & Rosieres (Midi-Pirenei, France) & V. vinifera $\mathrm{L}$. (Gamay) & 23 \\
\hline AA & Ehnen (Luxemburg) & $V$. vinifera $\mathrm{L}$. & 5 \\
\hline $\mathrm{AB}$ & Lobão da Beira (Aveiro, Portugal) & $V$. vinifera $\mathrm{L}$. & 14 \\
\hline $\mathrm{AC}$ & Lisboa (Lisboa, Portugal) & V. vinifera $\mathrm{L}$. & 2 \\
\hline $\mathrm{AD}$ & Sabugosa (Tondela, Portugal) & V. vinifera L. (Touriga Nacional) & 17 \\
\hline $\mathrm{AE}$ & Pècs (Baranya, Hungary) & V. vinifera L. & 6 \\
\hline $\mathrm{AF}$ & Dula (Eger, Hungary) & V. vinifera L. (Blauburger) & 4 \\
\hline AG & Dula (Eger, Hungary) & V. vinifera L. (Kèkfrancos) & 4 \\
\hline $\mathrm{AH}$ & Demjen (Eger, Hungary) & V. vinifera L. (Leanyka) & 4 \\
\hline AI & Demjen (Eger, Hungary) & V. vinifera $\mathrm{L}$. (Zenit) & 3 \\
\hline
\end{tabular}


the corresponding 25 clusters were used for further analysis. Isolations and DNA extraction were as reported above.

Polymerase chain reaction amplification and sequencing. The ITS1-ITS2 region, fragment of the $\beta$-tubulin gene, and fragment of the calmodulin gene were amplified with the primers ITS4 and ITS5 (White et al. 1990), Bt2a and Bt2b (Glass and Donaldson 1995), and CL1 and CL2A (O'Donnell et al. 2000), respectively. Reaction conditions consisted of $0.5 \mu \mathrm{l}$ of $10 \mu \mathrm{M}$ dNTP, $0.25 \mu \mathrm{l}$ of $1 \mu \mathrm{M}$ each primer, $2.5 \mu \mathrm{l}$ of $10 \times$ DreamTaq Green Buffer (Thermo Fisher Scientific Inc.), $0.25 \mu \mathrm{l}$ of DreamTaq DNA Polymerase (5 U/ $\mu \mathrm{l})$ (Thermo Fisher Scientific Inc.), $3 \mu$ of DNA, and water to a final volume of $25 \mu \mathrm{l}$. Polymerase chain reaction (PCR) cycling parameters for the ITS1-ITS2 region and fragment of the $\beta$-tubulin gene were 3 min of initial denaturation at $94^{\circ} \mathrm{C} ; 35$ cycles of $95^{\circ} \mathrm{C}$ for
$30 \mathrm{~s}$ and annealing for $30 \mathrm{~s}$ at $50^{\circ} \mathrm{C}$, extended at $72^{\circ} \mathrm{C}$ for $30 \mathrm{~s}$; and a final 7 -min extension at $72^{\circ} \mathrm{C}$. PCR cycling parameters for the calmodulin gene were $5 \mathrm{~min}$ of initial denaturation at $94^{\circ} \mathrm{C} ; 35$ cycles of $94^{\circ} \mathrm{C}$ for $50 \mathrm{~s}$ and annealing for $50 \mathrm{~s}$ at $55^{\circ} \mathrm{C}$, extended at $72^{\circ} \mathrm{C}$ for $1 \mathrm{~min}$; and a final 7 -min extension at $72^{\circ} \mathrm{C}$. Amplification products were detected on agarose gels $(1 \% \mathrm{wt} / \mathrm{vol})$ stained with ethidium bromide in $1 \times$ Tris-acetate EDTA buffer and purified using ExoSAPIT (USB Corporation), according to the manufacturer's protocol.

Amplification products were sequenced at the Centre for Biotechnological Services (CIBIACI) of the University of Florence with an ABI Prism $310 \mathrm{CE}$. Direct sequencing of amplified DNA was done in both directions from independent amplification reactions as above, with the necessary modifications for direct PCR sequencing.

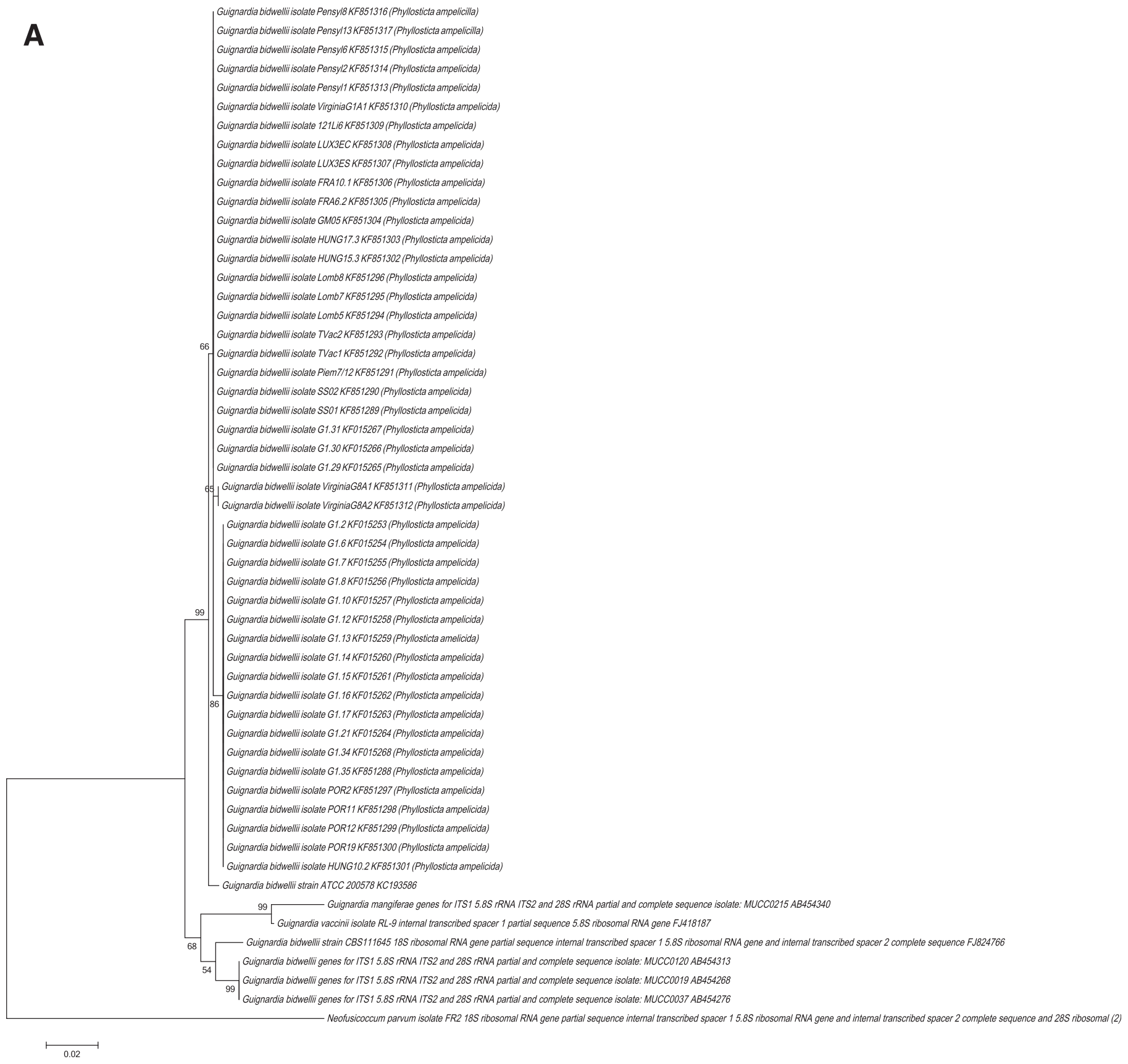

Continued on next page Fig. 2. A, Internal transcribed spacer (ITS) maximum-likelihood tree; $\mathbf{B}, \beta$-tubulin maximum-likelihood tree; and $\mathbf{C}$, calmodulin maximum-likelihood tree of Phyllosticta ampelicida strains from different hosts of the family Vitaceae. Bootstrap values at the nodes. D, Maximum-likelihood tree resulting from the concatenated ITS, $\beta$-tubulin, and calmodulin dataset. 
Pathogen identification. Nucleotide sequences of $P$. ampelicida isolates from $V$. vinifera, $V$. lambrusca, Parthenocissus quinquefolia, and $P$. tricuspidata, as well as Neofusicoccum parvum (used as outgroup), were retrieved from GenBank. BLAST probing of the
DNA databases was performed with the BLASTN option of the BLAST program (Altschul et al. 1997). Sequences were aligned with CLUSTAL W (Thompson et al. 1994). Each alignment was checked and corrected manually when necessary. The dendrograms
B
Guignardia bidwellii strain Sb25.7 calmodulin gene partial cds GU991586

Guignardia bidwellii strain Ti34.1.8 calmodulin gene partial cds GU991596

Guignardia bidwellii isolate Pensyl13 KF831471 (Phyllosticta ampelicida)

Guignardia bidwellii isolate Pensyl8 KF831470 (Phyllosticta ampelicida)

Guignardia bidwellii isolate Pensyl1 KF831467 (Phyllosticta ampelicida)

Guignardia bidwellii isolate VirginiaG1A1 KF831464 (Phyllosticta ampelicida)

Guignardia bidwellii isolate LUX3EC KF831462 (Phyllosticta ampelicida)

Guignardia bidwellii isolate GM05 KF831458 (Phyllosticta ampelicida)

Guignardia bidwellii isolate HUNG17.3 KF831457 (Phyllosticta ampelicida)

Guignardia bidwellii isolate HUNG15.3 KF831456 (Phyllosticta ampelicida)

Guignardia bidwellii isolate HUNG10.2 KF831455 (Phyllosticta ampelicida)

Guignardia bidwellii isolate TVAC2 KF831447 (Phyllosticta ampelicida)

Guignardia bidwellii isolate TVAc1 KF831446 (Phyllosticta ampelicida)

Guignardia bidwellii isolate G1.30 KF831440 (Phyllosticta ampelicida)

Guignardia bidwellii isolate G1.29 KF831439 (Phyllosticta ampelicida)

Guignardia bidwellii isolate G1.21 KF831438 (Phyllosticta ampelicida)

Guignardia bidwellii isolate G1.17 KF831437 (Phyllosticta ampelicida)

Guignardia bidwellii isolate G1.16 KF831436 (Phyllosticta ampelicida)

Guignardia bidwellii isolate G1.15 KF831435 (Phyllosticta ampelicida)

Guignardia bidwellii isolate G1.14 KF831434 (Phyllosticta ampelicida)

Guignardia bidwellii isolate G1.13 KF831433 (Phyllosticta ampelicida)

Guignardia bidwellii isolate G1.12 KF831432 (Phyllosticta ampelicida)

Guignardia bidwellii isolate G1.10 KF831431 (Phyllosticta ampelicida)

Guignardia bidwellii isolate G1.8 KF831430 (Phyllosticta ampelicida)

95 Guignardia bidwellii isolate G1.6 KF831428 (Phyllosticta ampelicida)

Guignardia bidwellii isolate G1.7 KF831429 (Phyllosticta ampelicida)

Guignardia bidwellii isolate G1.34 KF831441 (Phyllosticta ampelicida)

Guignardia bidwellii isolate G1.35 KF831442 (Phyllosticta ampelicida)

Guignardia bidwellii isolate SS01 KF831443 (Phyllosticta ampelicida)

Guignardia bidwellii isolate SS02 KF831444 (Phyllosticta ampelicida)

Guignardia bidwellii isolate Piem7.12 KF831445 (Phyllosticta ampelicida)

Guignardia bidwellii isolate Lomb5 KF831448 (Phyllosticta ampelicida)

Guignardia bidwellii isolate Lomb7 KF831449 (Phyllosticta ampelicida)

Guignardia bidwellii isolate Lomb8 KF831450 (Phyllosticta ampelicida)

Guignardia bidwellii isolate POR2 KF831451 (Phyllosticta ampelicida)

Guignardia bidwellii isolate POR11 KF831452 (Phyllosticta ampelicida)

Guignardia bidwellii isolate POR12 KF831453 (Phyllosticta ampelicida)

Guignardia bidwellii isolate POR19 KF831454 (Phyllosticta ampelicida)

Guignardia bidwellii isolate FRA6.2 KF831459 (Phyllosticta ampelicida)

Guignardia bidwellii isolate 121 Li6 KF831463 (Phyllosticta ampelicida)

Guignardia bidwellii isolate Pensyl2 KF831468 (Phyllosticta ampelicida)

Guignardia bidwellii isolate Pensyl6 KF831469 (Phyllosticta ampelicida)

Guignardia bidwellii strain Sb28.3 calmodulin gene partial cds GU991598

Guignardia bidwellii strain Ti18.5.1 calmodulin gene partial cds GU991600

Guignardia bidwellii isolate VirginiaG8A1 KF831465 (Phyllosticta ampelicida)

Guignardia bidwellii isolate VirginiaG8A2 KF831466 (Phyllosticta ampelicida)

Neofusicoccum parvum UCRNP2 chromosome Unknown NP2 03 scaffold 440 whole genome shotgun sequence KB916078 


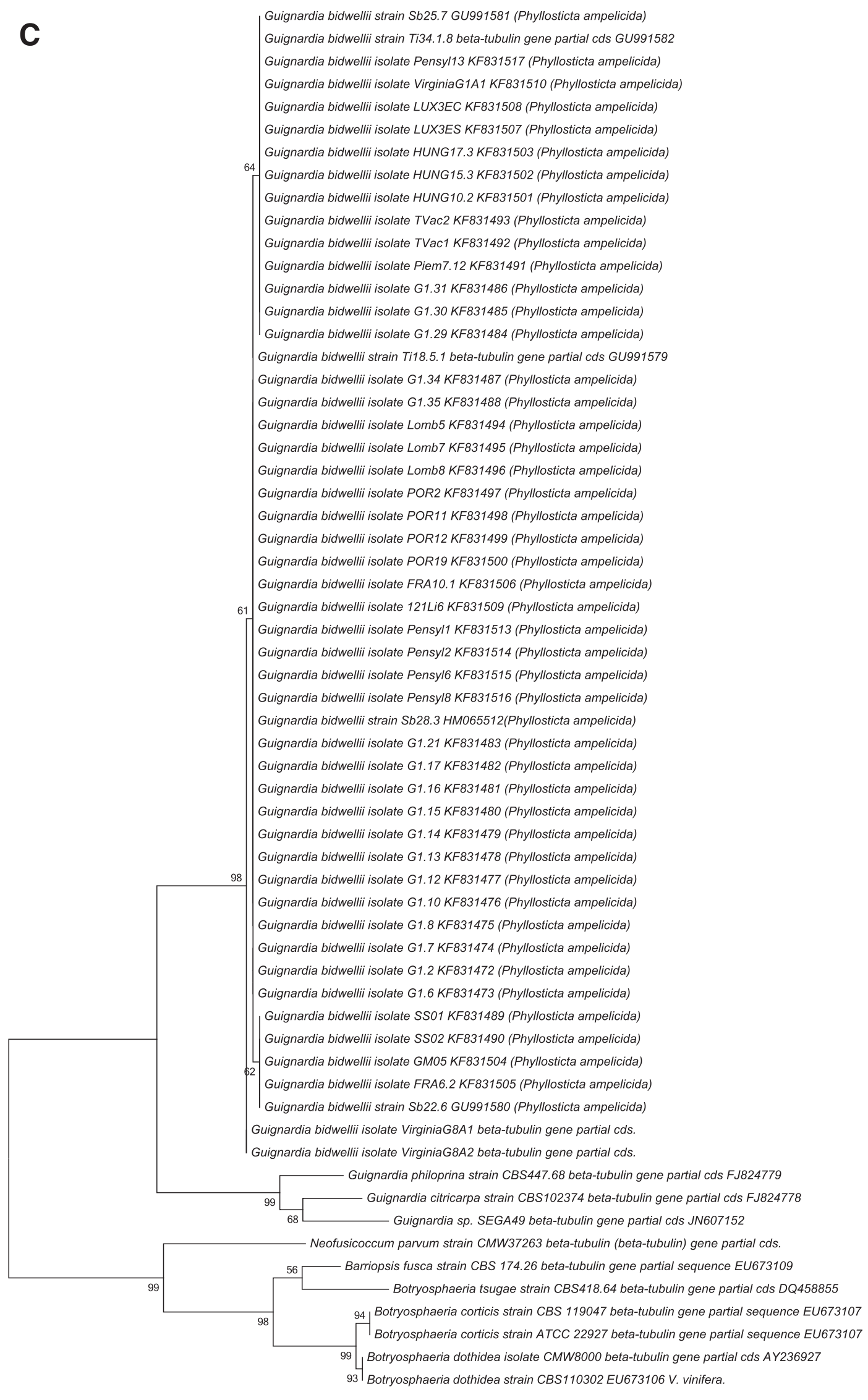

Fig. 2. Continued from previous page. 
were constructed by the maximum-likelihood method (Felsenstein and Churchill 1996) using PHYLIP software (version 3.695) by Joseph Felsenstein.

Microsatellite analyses. The samples used for $n$ SSR analysis are listed in Table 2 and primer pairs are as reported by NarduzziWicht et al. (2014). PCR amplification was performed in 5- $\mu 1$ reactions containing $2.5 \mu \mathrm{l}$ of $2 \times$ Qiagen Multiplex, $0.5 \mu \mathrm{l}$ of both forward and reverse primers, $0.5 \mu \mathrm{l}$ of $5 \times \mathrm{Q}$-Sol, $0.5 \mu \mathrm{l}$ of doubledistilled $\mathrm{H}_{2} \mathrm{O}$, and $1 \mu \mathrm{l}$ of DNA. PCR cycle parameters were $15 \mathrm{~min}$ of initial denaturation at $95^{\circ} \mathrm{C} ; 37$ cycles of $94^{\circ} \mathrm{C}$ for $40 \mathrm{~s}$ and annealing for $90 \mathrm{~s}$ at $55^{\circ} \mathrm{C}$, extended at $72^{\circ} \mathrm{C}$ for $90 \mathrm{~s}$; and a final $30-\mathrm{min}$ extension at $60^{\circ} \mathrm{C}$. Amplicons for the SSR analysis were eluted at a rate of 1:50 and sequenced with a 3730 Genetic Analyzer (Life Technologies, Applied Biosystems); genotyping was performed with Gene Mapper (v. 4.0; Life Technologies, Applied Biosystems).

Microsatellite data analyses. General estimates of genetic diversity from $n$ SSR data were calculated using SPAGeDi 1.3a (Hardy and Vekemans 2002): number of alleles, allele frequency, and genetic diversity, according to Nei (1987). Statistical significance was determined by jack-knifed estimators (Sokal and Rohlf 1995) after 20,000 permutations. Wright's fixation index, averaged over all loci, was calculated, and deviations from Hardy-Weinberg expectations were determined using GENEPOP 3.3 (Raymond and Rousset 1995). $F$ statistics and null alleles were calculated according to Weir and Cockerham (1984). Pairwise comparisons of fixation index $\left(\mathrm{F}_{\mathrm{ST}}\right)$ values were tested for significance, and critical values were adjusted for multiple tests with the Bonferroni correction. To examine the relationship between the genetic distance and the geographic distance, a Mantel test on the matrix of $\mathrm{F}_{\mathrm{ST}}$ values and that of the geographic distances was performed (50,000 permutations) using GENEPOP 3.3.

Population structure was inferred using a model-based clustering algorithm implemented in STRUCTURE v.2.3 (Falush et al. 2003, 2007; Pritchard et al. 2000) and the empirical statistic K (Earl and vonHoldt 2012; Evanno et al. 2005) to determine the number of subpopulations $(\mathrm{K})$. The default model parameters and varying $\mathrm{K}$ from 1 to 10 were used for both plots to run STRUCTURE. Each run consisted of 250,000 burn-in iterations and 1,000,000 data collection iterations, and was replicated 20 times.

Spatial subpopulation structure was inferred by a Bayesian Monte Carlo Markov Chain method implemented in Geneland package (version 3.0) (Guillot et al. 2009) under the R Language and Environment for Statistical Computing software, as described by Guillot et al. (2005 a,b, 2008). Ten independent Monte Carlo Markov Chain runs were performed with the following settings: $1,000,000$ iterations with 100 thinning intervals and a burn-in period of 250,000, using the correlated allele frequencies model. The maximum number of populations was set to 20. A map of posterior probabilities (membership) was obtained by Post-Process

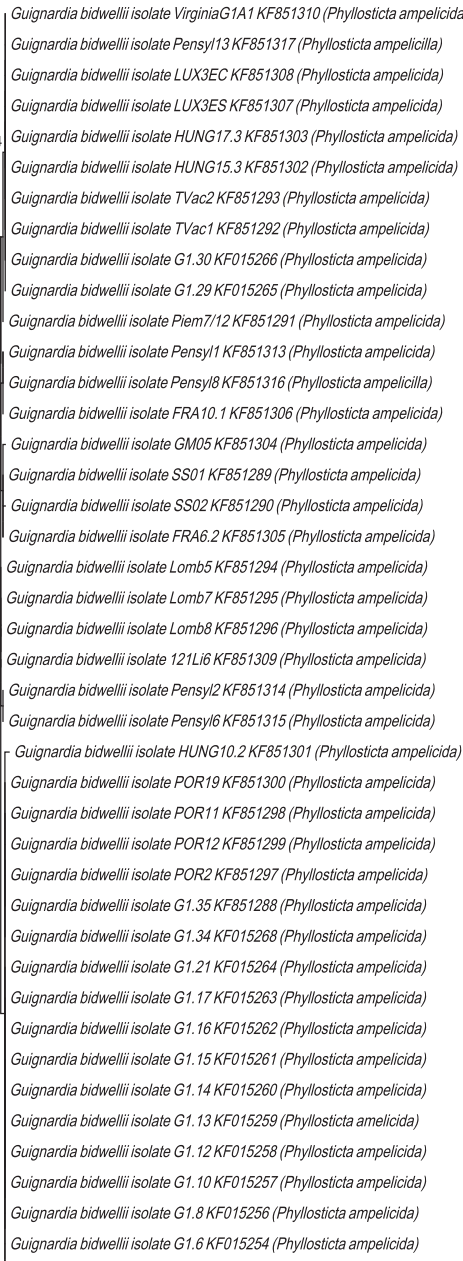

Fig. 2. Continued from previous page. 
Chain and Post Tessellation functions into Geneland by tesselling the landscape at a resolution of $1 \mathrm{~m}$. Null alleles for $n$ SSR were calculated by Geneland (version 3.0) (Guillot et al. 2008).

\section{RESULTS}

Pathogen identification. Maximum-likelihood trees were constructed for the ITS region, $\beta$-tubulin, and calmodulin sequences with sequence lengths after alignment of 628,333 , and $592 \mathrm{bp}$, respectively. A fourth tree was prepared from concatenated sequences with total length of 1,524 bp.

In the ITS tree, all strains of Phyllosticta ampelicida from Vitis spp. clustered in a single cluster, whereas the strains from other hosts (Parthenocissus quinquefolia and $P$. tricuspidata) formed a separate cluster (Fig. 2A). In the tree, the samples studied all grouped in a single cluster in all dendrograms, confirming that all strains belong to Phyllosticta ampelicida (Fig. 2B, C, and D).

nSSR analysis. Among 421 isolates analyzed, the $n$ SSR analysis allowed the detection of 56 haplotypes. Five haplotypes comprised $59.38 \%$ of the whole population. Haplotype 9 (H9) was found in 111 samples $(26.37 \%)$, H38 was found in 58 samples (frequency

TABLE 3. Number of unique and shared haplotypes and vine regions in which they were found

\begin{tabular}{lrrrr}
\hline & & \multicolumn{3}{c}{ Haplotypes } \\
\cline { 3 - 5 } Locality & Samples & Total & Unique & Shared \\
\hline Italy & & & & \\
$\quad$ Tuscany & 201 & 28 & 16 & 12 \\
Friuli & 11 & 1 & 0 & 1 \\
Liguria & 54 & 9 & 5 & 4 \\
Lombardy & 11 & 3 & 0 & 3 \\
Piedmont & 16 & 2 & 0 & 2 \\
$\quad$ Sardinia & 2 & 2 & 1 & 1 \\
Veneto & 3 & 1 & 0 & 1 \\
France & 23 & 10 & 2 & 8 \\
Germany & 7 & 4 & 0 & 4 \\
Luxembourg & 5 & 5 & 4 & 1 \\
Portugal & 33 & 6 & 1 & 5 \\
Hungary & 21 & 1 & 0 & 1 \\
United States & & & & \\
$\quad$ Virginia & 34 & 13 & 13 & 0 \\
\hline
\end{tabular}

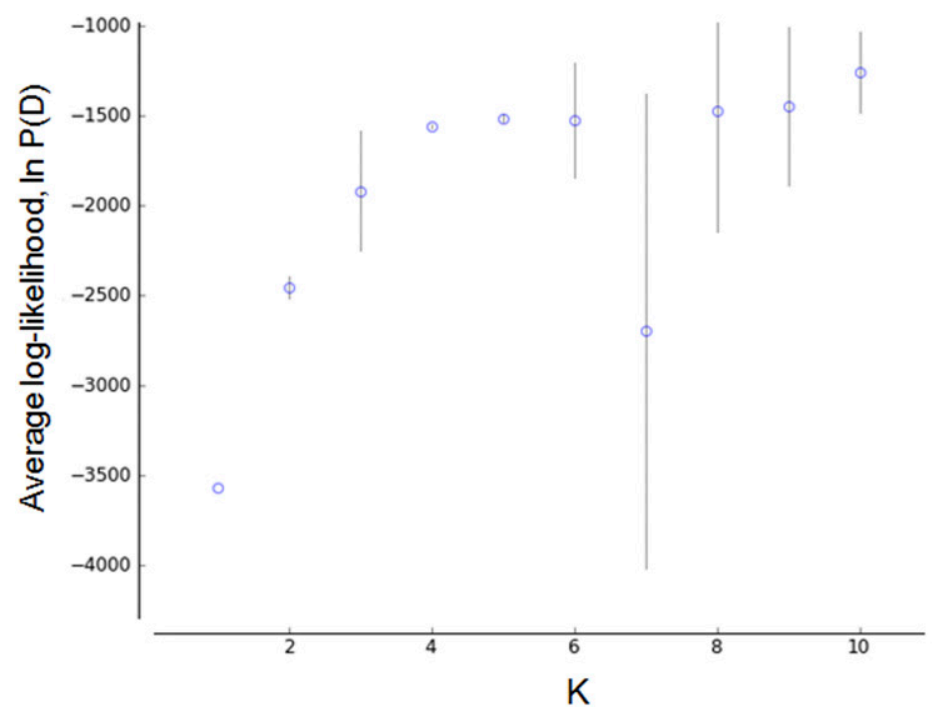

$13.78 \%$ ), and $\mathrm{H} 14$ was present in 35 samples (frequency $8.31 \%$ ). Both $\mathrm{H} 29$ and $\mathrm{H} 55$ were found in 23 samples (frequency $=5.46 \%$ ). Of the remaining haplotypes, only nine (H5, H10, H13, H19, H23, $\mathrm{H} 30, \mathrm{H} 39, \mathrm{H} 45$, and $\mathrm{H} 46$ ) reached frequencies greater than $1 \%$, found in 5 to 9 samples. The remaining 42 haplotypes ( $75 \%$ of the total) resulted in a frequency lower than $1 \%$, meaning that almost half of the haplotypes were found from one to four times. All American haplotypes were unique and no haplotype shared with European populations was found (Table 3). $\mathrm{H} 9$ and $\mathrm{H} 38$ are the haplotypes most widespread in Europe and both were found in 7 of the 14 localities sampled. Despite the high number of samples collected in Tuscany, H38 was not found there but it did occur in Friuli, Veneto, Piedmont, France, Germany, Portugal, and Hungary; whereas H9 was found in Italy in all Tuscan localities, and in Liguria, Lombardy, Sardinia, France, and Portugal. A relevant percentage of unique haplotypes (42.42\%) was found in the Tuscan population, which comprised 152 samples from Florence and 49 from the rest of the region (total =201). High numbers of unique haplotypes were found among the Liguria and the Luxembourg populations, where four of nine (Liguria), and all five (Luxemburg) samples were unique.

Spatial structure of genetic diversity. The spatial structure analysis of genetic diversity in $P$. ampelicida populations identified four subpopulations. The log-likelihoods from runs of STRUCTURE with $\mathrm{K}$ of 1 to 20 had a clear peak at $\mathrm{K}=4$ (Fig. 3) and were spatially explicit in clustering analyses using GENELAND (Fig. 4, European distribution). The U.S. subpopulation (named cluster A) was spatially isolated from each subpopulation, as demonstrated by maps of posterior probabilities (Fig. 4). Moreover, it was genetically isolated, as demonstrated by high values of $\mathrm{F}_{\mathrm{ST}}$ and $\mathrm{D}_{\mathrm{s}}$, but it presents the highest level of genetic diversity among strains (Table 4). The European subpopulations were not spatially isolated and presented a significantly similar genetic diversity among strains (Table 4). The subpopulation named cluster A appears to be the most genetically isolated, as shown by $\mathrm{F}_{\mathrm{ST}}$ and $\mathrm{D}_{\mathrm{s}}$. In contrast, subpopulations $\mathrm{D}$ and $\mathrm{C}$ were more similar (Table 4).

Microspatial structure of genetic diversity in a vineyard. The spatial structure analysis of genetic diversity in a 35-year-old vineyard $\left(5,000 \mathrm{~m}^{2}\right)$ growing in the surroundings of Florence, Italy (Sangiovese and Trebbiano grape) identified three subpopulations. The log-likelihoods from runs of STRUCTURE with K of 1 to $20 \mathrm{had}$ a clear peak at $\mathrm{K}=3$ (data not shown) and were spatially explicit in clustering analyses using GENELAND (Fig. 5). No gene flow was

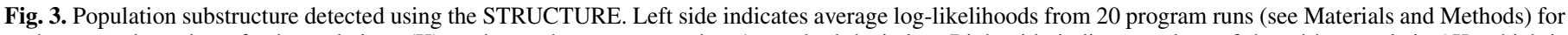

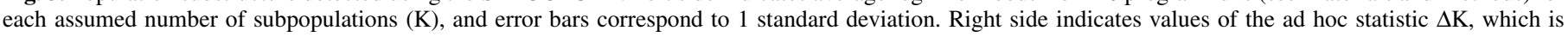

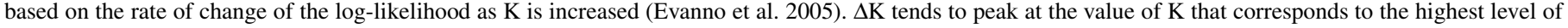
hierarchical substructure. 
detected among strains belonging to the three different clusters but there was gene flow within each cluster. Actually, the $\mathrm{F}_{\mathrm{ST}}$ and genetic diversity values among clusters were very high (Table 5). In contrast, genetic analyses of the population of the pathogen present in a single small vineyard confirmed the very high genetic variability of the pathogen, with the presence of up to 24 different haplotypes within the selected plots.

\section{DISCUSSION}

The present study, although it was not focused on the detection of different species within the $P$. ampelicida complex, confirms the genetic variability of the fungus and assigns the pathogen isolated from infected samples showing typical black rot symptoms to P. ampelicida.
The use of microsatellites ( $n \mathrm{SSR}$ ) confirmed the presence of a high degree of genetic variability in this fungus. Among 421 berries analyzed from a worldwide set of infected samples, 56 haplotypes were found. This number and the low value of their frequencies indicate that sexual reproduction of the fungus is important in the diffusion of the disease and its evolution. The main part of the population investigated belonged to the same five haplotypes, whereas 40 of the 56 were unique and only 16 were shared. Among the latter, H55, found in Florence and shared with the rest of the region, could be considered typical of this area. $\mathrm{H} 9$ and $\mathrm{H} 38$, as well as being the most frequent, were also the two most shared, with the first one, H9, strongly present in Tuscany, Sardinia, and Portugal but not in the northeastern Italian regions; while the second one, H38, is present in the other European countries and in the northeast of Italy. Considering that the DNA analyzed in this study was extracted from mummified berries and considering such a great spread of different
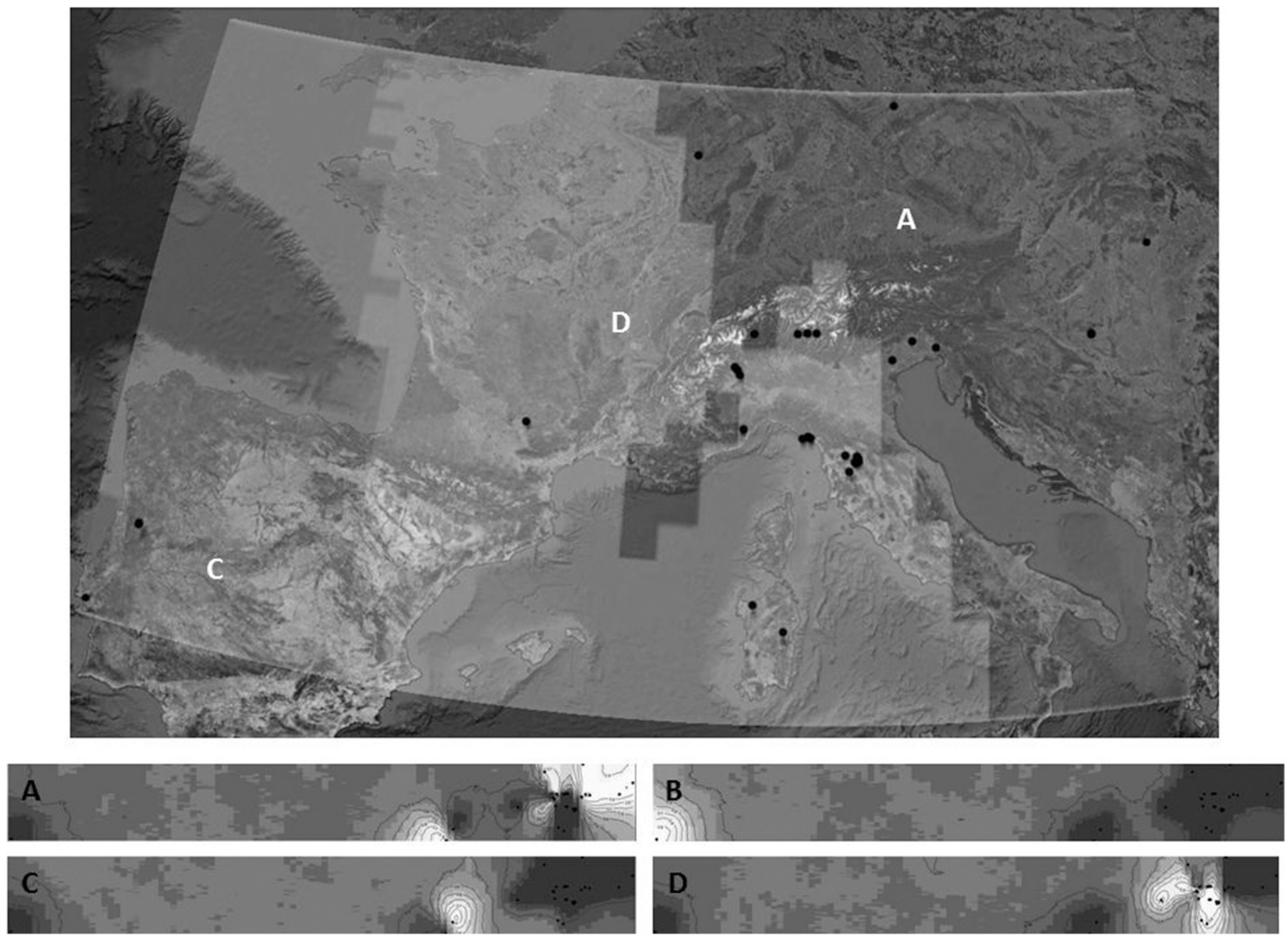

Fig. 4. Results of Geneland analysis by nuclear microsatellite data of the Phyllosticta ampelicida European populations showing the spatial organization into three subpopulations (B, C, and D) and maps of posterior probabilities for each subpopulation (black indicates low gene flow and white indicates high gene flow). Map obtained from Google Earth.

TABLE 4. Genetic diversity (D) within four subpopulations, and matrix of pairwise $\mathrm{F}_{\mathrm{ST}}$ among the subpopulations (above diagonal) and genetic divergence ( $\mathrm{D}_{\mathrm{s}}$ ) among subpopulation (below diagonal) in the Phyllosticta ampelicida population

\begin{tabular}{lcccc}
\hline Subpopulations & $\mathrm{A}(\mathrm{D}=0.480)$ & $\mathrm{B}(\mathrm{D}=0.250)$ & $\mathrm{C}(\mathrm{D}=0.268)$ & 0.547 \\
$\mathrm{~A}$ & $\ldots$ & 0.618 & 0.241 & \\
$\mathrm{~B}$ & 1.654 & $\ldots$ & $\ldots$ & 0.618 \\
C & 1.332 & 0.114 & $0.257)$ \\
$\mathrm{D}$ & 1.420 & 0.126 & 0.057 & 0.137 \\
\hline
\end{tabular}


haplotypes, we can deduce that infection of berries by ascospores is far more probable than by conidia. The wide variety of haplotypes found on berries suggests that infections by sexual spores is an important stage in the beginning of the epidemic and we can speculate that secondary infections derived from pycnidia following the development of leaf symptoms do not play an important role in the disease on bunches, as suggested by Jermini and Gessler (1996) on the basis of field observations.

The microsatellite analysis demonstrates that all haplotypes are divided into four main subpopulations (Figs. 3 and 4): one comprising the American haplotypes; a second group comprising a Portuguese subpopulation; another group comprising the Italian and French subpopulations; and the last one made up of the rest of the European populations, part of the Portuguese haplotypes, and those from northeastern Italy. This geographical grouping is in agreement with what was previously stated. The distinction of the American strains is confirmed, while the haplotypes nearer to them are from Italy (Tuscany and Sardinia). Within these two groups (American and European), the high "mean diversity population" value shows that variability is highest within the investigated population. This close relationship could even suggest the hypothesis that the recent outbreak of the disease in Sardinia could be caused by a recent introduction of strains of the pathogen from America, whereas the high variability recorded in Tuscany suggests that either there were multiple introductions or the pathogen was in the area for quite a long time.

The presence of some American haplotypes (A) in France is in accordance with the first observations of the disease in Europe. The disease was first seen in France following the introduction of American vines, confirming the hypothesis that the disease was introduced from North America. The other three subpopulations indicate that three different introductions of the pathogen occurred in the different European vine areas. Subpopulation B, present in France and Tuscany, confirms the observations by Martelli (1891) of the disease in Tuscany 6 years after the first records in France, suggesting that the disease arrived in Italy from France. The

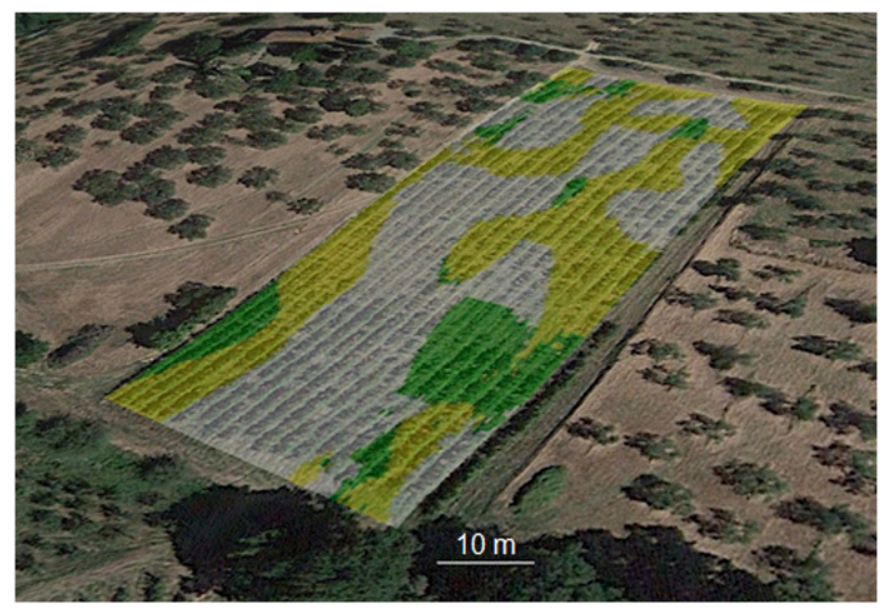

Fig. 5. Results of Geneland analysis by nuclear microsatellite data of the Phyllosticta ampelicida population in the vineyard in Florence showing the spatial organization into three subpopulations. Map obtained from Google Earth.

TABLE 5. Genetic diversity (D) within three subpopulations, and matrix of pairwise $\mathrm{F}_{\mathrm{ST}}$ among subpopulations (above diagonal) and genetic divergence $\left(\mathrm{D}_{\mathrm{s}}\right)$ among subpopulation (below diagonal) in the Phyllosticta ampelicida population in the vineyard in Florence

\begin{tabular}{lccc}
\hline Subpopulations & $1(\mathrm{D}=0.224)$ & $2(\mathrm{D}=0.161)$ & $3(\mathrm{D}=0.099)$ \\
\hline 1 & $\ldots$ & 0.668 & 0.313 \\
2 & 0.574 & $\ldots$ & 0.782 \\
3 & 0.061 & 0.731 & $\ldots$ \\
\hline
\end{tabular}

presence in Portugal of two subpopulations (B and C) suggests two separate introductions of the pathogen, one from France or Italy (subpopulation B) and a second from America. Population D, found in a wide vine area comprising Central Europe, Eastern Europe, and northeast Italy, is in accordance with the observations of the disease in Germany (Lüstner 1935) and ex-Yugoslavia (Rui 1935), for the first time, during the 1930s. It is known that the introduction of the disease in the northeast of Italy was from ex-Yugoslavia (Rui et al. 1987) at the end of the 1980s. In Hungary, the disease could have been introduced in 1999 from Germany or ex-Yugoslavia (Mikulás et al. 1999).

The presence of haplotypes shared between Italy and the rest of Europe confirms that the pathogen has been present in Italy for a long time, whereas the large number of haplotypes (38) found in the northeast of Italy and in Hungary confirms the introduction of the pathogen from Eastern Europe to Italy. The high rate of different haplotypes in the total samples obtained from France $(52.17 \%)$ strongly suggests that the fungus arrived in Europe for the first time in France. The American origin of the pathogen is underlined by the same high rate $(38.23 \%)$ of haplotype variability found in Virginia, as expected in the land of origin.

Analysis of the microspatial structure of genetic diversity within a vineyard suggests that sexual reproduction of the pathogen is an important stage in disease progress in the vineyard, with a numerically dominant haplotype that can cross with a wide range of individuals, generating new strains, possibly with a different or greater virulence. Further studies are necessary to understand why different clusters in which gene flow is only within the cluster are present, and their significance in disease development.

This study demonstrates the importance of sexual reproduction in the spread of the pathogen and in the outbreak of the disease. It confirms that the origin of the pathogen is North America and that the first introduction into Europe was in France. It suggests that the pathogen was introduced to northeastern Italy from Eastern Europe. The proximity of the haplotypes found in Europe with those from the northeast of Italy, as well as some from Tuscany, suggests that, in these Italian vine areas, the disease spread from northern Europe and France, and that these strains may be more ancient than the ones that caused devastating outbreaks of the disease in the recent years in some Italian vine areas.

\section{ACKNOWLEDGMENTS}

We thank all those who kindly helped us in collecting black rot samples and A. Phillips for his careful reading and priceless advice during the preparation of the manuscript.

\section{LITERATURE CITED}

Altschul, S. F., Madden, T. L., Schäffer, A. A., Zhang, J., Zhang, Z., Miller, W., and Lipman, D. J. 1997. Gapped BLAST and PSI-BLAST: A new generation of protein database search programs. Nucleic Acids Res. 25: 3389-3402.

Earl, D. A., and vonHoldt, B. M. 2012. STRUCTURE HARVESTER: A website and program for visualizing STRUCTURE output and implementing the Evanno method. Conserv. Genet. Resour. 4:359-361.

Evanno, G., Regnaut, S., and Goudet, J. 2005. Detecting the number of clusters of individuals using the software STRUCTURE: A simulation study. Mol. Ecol. 14:2611-2620

Falush, D., Stephens, M., and Pritchard, J. K. 2003. Inference of population structure using multilocus genotype data: Linked loci and correlated allele frequencies. Genetics 164:1567-1587.

Falush, D., Stephens, M., and Pritchard, J. K. 2007. Inference of population structure using multilocus genotype data: Dominant markers and null alleles. Mol. Ecol. Notes 7:574-578.

Felsenstein, J., and Churchill, G. A. 1996. A hidden Markov model approach to variation among sites in rate of evolution. Mol. Biol. Evol. 13:93-104.

Galet, P. 1977. Les maladies et les parasites de la vigne. Tome 1. Le maladies due à des végétaux. Le Paysan du Midi, Montpellier, France.

Gessler, C., Blaise, P., and Jermini, M. 2006. Black rot on the hybrid Vitis cultivar Isabella. IOBC/WPRS Bull. 29:95-102. 
Gessler, C., Foiada, F., Jermini, M., and Pertot, I. 2008. Control of black rot (Guignardia bidwellii) on the hybrid Vitis cultivar Isabella. IOBC/WPRS Bull. 36:101-105.

Glass, N. L., and Donaldson, G. C. 1995. Development of primer sets designed for use with the PCR to amplify conserved genes from filamentous ascomycetes. Appl. Environ. Microbiol. 61:1323-1330.

Guillot, G., Estoup, A., Mortier, F., and Cosson, J. F. 2005a. A spatial statistical model for landscape genetics. Genetics 170:1261-1280.

Guillot, G., Leblois, R., Coulon, A., and Frantz, A. C. 2009. Statistical methods in spatial genetics. Mol. Ecol. 18:4734-4756.

Guillot, G., Mortier, F., and Estoup, A. 2005b. Geneland: A computer package for landscape genetics. Mol. Ecol. Notes 5:712-715.

Guillot, G., Santos, F., and Estoup, A. 2008. Analysing georeferenced population genetics data with Geneland: A new algorithm to deal with null alleles and a friendly graphical user interface. Bioinformatics 24: 1406-1407.

Hardy, O. J., and Vekemans, X. 2002. SPAGeDi: A versatile computer program to analyse spatial genetic structure at the individual or population levels. Mol. Ecol. 2:618-620.

Harms, M., Holz, B., Hoffman, C., Lipps, H. P., and Silvanus, W. 2005. Occurrence of Guignardia bidwellii, the causal fungus of Black Rot on grapevine, in the vine growing areas of Rhineland-Palatinate, Germany. Pages 127-132 in: BCPC Symp. Proc. Humboldt University Press, Berlin.

Hoffman, L. E., and Wilcox, W. F. 2002. Utilizing epidemiological investigations to optimize management of grape Black rot. Phytopathology 92: 676-680.

Holz, B. 2003. Schwarzfäule der Rebe in Mosel-Saar-Ruwer: Plötzlich und unverhofft. Dtsch. Weinmagazin 6:26-29.

Jermini, M., and Gessler, C. 1996. Epidemiology and control of grape black rot in southern Switzerland. Plant Dis. 80:322-325.

Lüstner, G. 1935. Auftreten der Schwarzfaule (Black rot) der Rebe in Deutschland. Nachrichtenbl. Dtsch. Pflanzenschutzdienst (Berlin) 15:27.

Luttrell, E. S. 1946. Black rot of Muscadine grapes. Phytopathology 36: 905-924

Luttrell, E. S. 1948. Physiologic specialization in Guignardia bidwellii, cause of Black rot of Vitis and Parthenocissus species. Phytopathology 38: 716-723.

Martelli, U. 1891. Il black rot sulle viti presso Firenze. Nuovo G. Bot. Ital. 23: 604-610.

Mikulás, J., Lázár, J., and Nyesti, P. 1999. Hazai szőlőültetvényeink új gombabetegsé-gének (feketerothadás-(Guignardia bidwellii)) jelentősége Tokaj-hegyalján. Pages 25-26 in: 4. Tiszántúli Növényvédelmi Fórum (géntechnológia a növényvédelemben) [Transboundary Plant Protection Forum (Genetic Technology in Plant Protection)]. University of Agricultural Sciences, Faculty of Agriculture, Debrecen, Hungary.

Molitor, D., Augenstein, B., Mugnai, L., Rinaldi, P. A., Sofia, J., Hed, B., Dubuis, P.-H., Jermini, M., Kührer, E., Bleyer, G., Hoffmann, L., and Beyer, M. 2016. Composition and evaluation of a novel web-based decision support system for grape black rot control. Eur. J. Plant Pathol. 144:785-798.

Molitor, D., and Berkelmann-Loehnertz, B. 2011. Simulating the susceptibility of clusters to grape black rot infections depending on their phonological development. Crop Prot. 30:1649-1654.

Molitor, D., and Beyer, M. 2014. Epidemiology, identification and disease management of grape black rot and potentially useful metabolites of black rot pathogens for industrial applications-A review. Ann. Appl. Biol. 165: 305-317.

Narduzzi-Wicht, B., Jermini, M., Gessler, C., and Broggini, G. A. L. 2014. Microsatellite markers for population studies of the ascomycete Phyllosticta ampelicida, the pathogen causing grape black rot. Phytopathol. Mediterr. 53: 470-479.

Nei, M. 1987. Molecular Evolutionary Genetics. Columbia University Press, New York.

O’Donnell, K., Nirenberg, H. I., Aoki, T., and Cigelnik, E. 2000. A multigene phylogeny of the Gibberella fujikuroi species complex: Detection of additional phylogenetically distinct species. Mycoscience 41:61-78.

Onesti, G., González-Domínguez, E., and Rossi, V. 2016. Accurate prediction of black rot epidemics in vineyards using a weather-driven disease model. Pest Manage. Sci. 72:2321-2329.

Pritchard, J. K., Stephens, M., and Donnelly, P. 2000. Inference of population structure using multilocus genotype data. Genetics 155:945-959.

Raymond, M., and Rousset, F. 1995. GENEPOP (version 1.2): Population genetics software for exact tests and ecumenicism. J. Hered. 86:248-249.

Reddick, D. 1911. The black rot disease of grapes. Cornell Univ. Agric. Exp. Stn. Bull. 293:289-364.

Rinaldi, P. A., Broggini, G. A. L., Gessler, C., Molitor, D., Sofia, J., and Mugnai, L. 2013. Guignardia bidwellii, the agent of grape black rot of grapevine, is spreading in European vineyards. Acta Phytopathol. Sin. 43:11.

Rinaldi, P. A., and Mugnai, L. 2012. Marciume nero degli acini, potenziale pericolo in viticoltura. Inf. Agrar. 15:68-71.

Rossman, A. Y., Crous, P. W., Hyde, K. D., and Hawksworth, D. L. 2015. Recommended names for pleomorphic genera in Dothideomycetes. IMA Fungus 6:507-523.

Rui, D. 1935. Il black rot o marciume nero dell'uva nell'isola di Veglia (Jugoslavia). Annuario della Regia. Stazione di viticoltura e di enologia di Conegliano 5:285-289.

Rui, D., Torresin, G. C., Pizzoli, L., and Carraro, S. 1987. Lotta guidata contro il black-rot della vite. Inf. Agrar. 38:53-58.

Sokal, R. R., and Rohlf, F. J. 1995. Biometry. W. H. Freeman, New York.

Thompson, J. D., Higgins, D. G., and Gibson, T. J. 1994. CLUSTAL W: Improving the sensitivity of progressive multiple sequence alignment through sequence weighting, position-specific gappenalties and weight matrix choice. Nucleic Acids Res. 22:4673-4680.

Tomoiaga, L., and Comsa, M. 2010. The strategy of optimization for combat the black rot of vine (Guignardia bidwellii), in the ecoclimatic conditions from vineyard Târnave. Page 500 in: Bulletin of University of Agricultural Sciences and Veterinary Medicine Cluj-Napoca. Horticulture 67(1). Cluj-Napoca, Romania.

Weir, B. S., and Cockerham, C. C. 1984. Estimating F-statistics for the analysis of population structure. Evolution 38:1358-1370.

White, T. J., Bruns, T., Lee, S., and Taylor, J. 1990. Amplification and direct sequencing of fungal ribosomal RNA genes for phylogenetics. Pages 315-322 in: PCR Protocols: A Guide to Methods and Applications. M. A. Innis, D. H. Gelfand, J. J. Sninsky, and T. J. White, eds. Academic Press.

Wicht, B., Perini, O., Jermini, M., Gessler, C., and Broggini, G. A. L. 2012. Molecular, proteomic and morphological characterization of the ascomycete Guignardia bidwellii, agent of grape black rot: A polyphasic approach to fungal identification. Mycologia 104:1036-1045.

Wikee, S., Dhanushka, U., Crous, P. W., Chukeatirote, E., McKenzie, H. C., Bahkali, A. H., Dai, D. Q., and Hyde, K. D. 2011. Phyllosticta-An overview of current status of species recognition. Fungal Divers. 51:43-61.

Wilcox, W. F., and Hoffman, L. E. 2015. Black rot. Pages 28-33 in: Compendium of Grape Diseases, Disorders, and Pests, Second Edition. W. F. Wilcox, W. D. Gubler, and J. K. Uyemoto, eds. American Phytopathological Society, St. Paul, MN.

Zhang, K., Zhang, N., and Cai, L. 2013. Typification and phylogenetic study of Phyllosticta ampelicida and P. vaccinii. Mycologia 105:1030-1042. 